\title{
Perception of Climate Change and Its Effects on Rural Livelihood in Katsina State, Nigeria
}

\author{
Murtala, A. M Arokoyu, S. B Weli., V. E.* \\ Department of Geography and Environmental management, \\ University of Port Harcourt, Choba, Rivers State, Nigeria
}

\begin{abstract}
This study investigated the perception of climate change and its effects on livelihood in Katsina state. This study adopted cross sectional research design. Data for this study were generated from the administration of questionnaire in the study area. Data analysis was achieved using the Kruskal Wallis test. Findings of the study include; the locals identified that there are changes in the characteristics of climate elements in the area indicating climate change. The locals also identified that as a result of climate change, they have witnessed increase in the loss of agricultural land and soil quality due to erosion and reduced soil fertility (70\%), reduced livestock productivity (55.6\%), increase in pest and disease incidence in livestock $(70 \%)$, increase in the cost of crop production $(60.7 \%)$, and increase in the rate of farmer poverty $(39.3 \%)$. The perception of the concept of climate change across the study area was significantly different at $\mathrm{P}<0.05\left(\chi^{2}(2)=, 21303.673\right)$ implying that, the consequences of climate change in the area also vary. The study strongly advocates, the application of climate smart agriculture, reforestation and massive public awareness about the causes and effects of climate change in the study area.
\end{abstract}

Keywords: climate-change, livelihood, semi-arid, greenhouse-gases

DOI: $10.7176 / \mathrm{JNSR} / 10-2-04$

Publication date: January $31^{\text {st }} 2020$

\section{Introduction}

Globally, the once suggested or proposed impacts of climate change are already evident (Enger and Smith, 2010; Abanigha, 2013; Abel \& Orunoye, 2013; Abraham, Bamidele, Adebola, \& Kobe, 2011; Ahmed \& Bisiku, 2006). This has manifested in increasing temperature rates and prolonged flood or drought conditions that affect agricultural activities and nature and the developing world is the expressed to be the most affected, due in part to the poor level of development and technological development (Okubokebena, Hope, \& Clayton 2014; Oluwo, 2013; Odjugo, \& Ikhuoria, 2003; Pascher, 2013; Sigmond, 2012; Spencer 2011; Terdoo \& Adekola 2014; Udeh, 2014).

The major cause of the changes in climate includes burning coal, oil, natural gas to heat our homes, power our cars, industrial plants emissions and the illuminating of our cities produces Carbon dioxide and other gases as by- products. Deforestation and clearing of land for agriculture also release significant quantities of such gases into the atmosphere (Enger and Smith, 2010; Abanigha, 2013; Abel \& Orunoye, 2013; Abraham, Bamidele, Adebola, \& Kobe, 2011; Ahmed \& Bisiku, 2006; Ajayi., 2009; ASSAR, 2015; Band, Gibson \& Abel, 2013; Coeven \& Helfare, 2014; Ebong, 2006). Over the last century, industrial and transportation sectors have also been emitting gases such as Carbon dioxide $\left(\mathrm{CO}_{2}\right)$ and methane $\left(\mathrm{CH}_{4}\right)$ to the atmosphere faster than natural processes can remove them (Enger \& Smith, 2010). During this time, atmospheric levels of these gases have increased steadily and are projected to continue their steep ascent as global economics grow. Record of past climate change date as far back as 160,000 years indicates close correlation between the concentration of gases in the atmosphere and global temperatures (Nkii, 2012). Computer simulations of climate data indicates that global temperatures will raise as atmospheric concentrations of carbon dioxide increase (Eager and Smith, 2010).

It is anticipated that climate variability and change would affect several aspects of human existence globally and in Nigeria it will have an overwhelming impact on agriculture and land use, ecosystem and biodiversity, human settlements, diseases, livelihood, hydrology and water resources. Mustapha, Undiandeye, and Gwary, (2012) pointed out that, with respect to agriculture and land use, climate change will likely elicit a significant change in agricultural production both in terms of the quantum of products as well as the location or area of production. Abubakar, (2001) noted a shift from the production of long duration guinea corm to millet, which requires shorter duration of rainfall. He further revealed in Borno, Yobe, Sokoto and Zamfara states the percentage production of Guinea corn and Millet was $70 \%$ and 30\% respectively in 1980, as at the year 2000, it has changed to $40 \%$ and $60 \%$ respectively. This clearly shows that rainfall duration and amount is fluctuating in northern Nigeria.

Climate change has also been found to either dry up rivers or reduce their depth, for instance, Odjugo and Ikhouria, (2003) revealed that that for the past 52 years (1950-2001) drastic ecological changes have occurred in the semi-arid region of Nigeria. While temperature has been on the increase, rainfall has been declining. This climatic change and the pressure on the land from farming, overgrazing, deforestation, and indiscriminate bush burning have led to desert encroachment and its associated ecological degradation, such as loss of vegetal cover, 
crops failure, and water scarcity (Okubokebena, Hope, \& Clayton 2014; Oluwo, 2013; Odjugo, \& Ikhuoria, 2003; Pascher, 2013; Sigmond, 2012; Spencer 2011; Terdoo \& Adekola 2014; Udeh, 2014). A case in point is Lake Chad, which had mean depth of $3 \mathrm{~m}$ in the early 1960s, is less than $2 \mathrm{~m}$ as at 2000 . The surface area of the lake which was $23,500 \mathrm{~km}^{2}$ in 1963 has shrunk to between 2,300 and $2,500 \mathrm{~km}^{2}$.

On the other hand livelihood comprises the capabilities, assets (stores, resources, claims and access) and activities required for a means of living. Livelihood is said to be sustainable when its source can cope with and recover from stress and shocks, maintain or enhance its capabilities and assets, and provide sustainable livelihood opportunities for the next generation; and which contributes net benefits to other livelihoods at the local and global levels and in the short and long term. Livelihood can also be expressed as comprising the capabilities, assets (including both material and social resources) and activities required for a means of living. A livelihood is sustainable when it can cope with and recover from stresses and shocks maintain or enhance its capabilities and assets, while not undermining the natural resource base. Scoones (1999) pointed out, that it is insufficient just to analyze the different aspects of livelihood; one must also analyze the institutional processes and organizational structures that link these various elements together. To do this, it is essential that livelihood analyses fully involve the local people to let their knowledge, perceptions, and interests be heard. Some of the example of livelihood assets are, food stocks, stores of value such as gold, jewelry, cash savings) and resources (e.g., land, water, trees, livestock, farm equipment), as well as intangible assets such as claims (i.e., demands and appeals which can be made for material, moral or other practical support) and access, which is the opportunity in practice to use a resource, store or service or to obtain information, material, technology, employment, food or income (Elisha., Sawa, \& Lawrence, 2017; Farauta, Egbule, Idrisa, \& Agu, 2011; Fediji, Adeoguk, \& Kaliada 2006; Fischer, Ben \& Etop, 2015; Gemade, \& Sima, 2015; Ishaya, \& Abaje, 2008; Ogba, \& Utang, 2008).

Krantz, (2001) argue that, livelihood and poverty reductions should be sustainable and he proposed three insights to better understand sustainable livelihood. The first is the realization that while economic growth may be essential for poverty reduction, there is not an automatic relationship between the two since it all depends on the capabilities of the poor to take advantage of expanding economic opportunities. Secondly, there is the realization that poverty - as conceived by the poor themselves - is not just a question of low income, but also includes other dimensions such as bad health, illiteracy, lack of social services, etc., as well as a state of vulnerability and feelings of powerlessness in general. Finally, it is now recognized that the poor themselves often know their situation and needs best and must therefore be involved in the design of policies and project intended to better their lot. As such, when the source of livelihood is impacted there are far reaching consequences for the inhabitants. When livelihood is affected the consequences on people in the less developed places is more intolerable as most have only one source of income. Therefore, the impact of climate change is anticipated to be severe on especially rural dwellers. This study is thus set out to assess the perception of climate change and its effects on rural livelihood and household income in Katsina state

\section{Materials and methods}

The semi-arid region of Katsina State in the North Western part of Nigeria is the study area for this research. Katsina state is one of the states in the North - Western region of Nigeria. The state was created on the

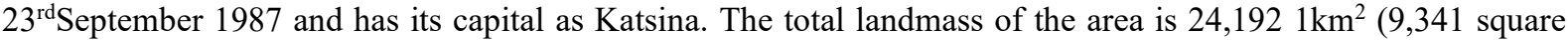
miles) and has a total population of 3,753,133 persons in 1991 census and 5,801, 584 persons in 2006 (NPC, 2006). Katsina State is located in the North - Western part of Nigeria and is bounded at the south by Kaduna State, at the East by Jigawa and Kano States, at the West by Zamfara State and at the North by the Sahara desert and republic of Niger (see Fig 1.1). Katsina state is located approximately between latitude $12^{0} 15^{\prime} 00^{\prime \prime}$ and $12^{0} 25^{\prime} 00^{\prime \prime} \mathrm{N}$ and longitude 7030'00" and 70500"00" E of the Greenwich meridian (National Geo-Spatial Intelligence Agency, 2015) 


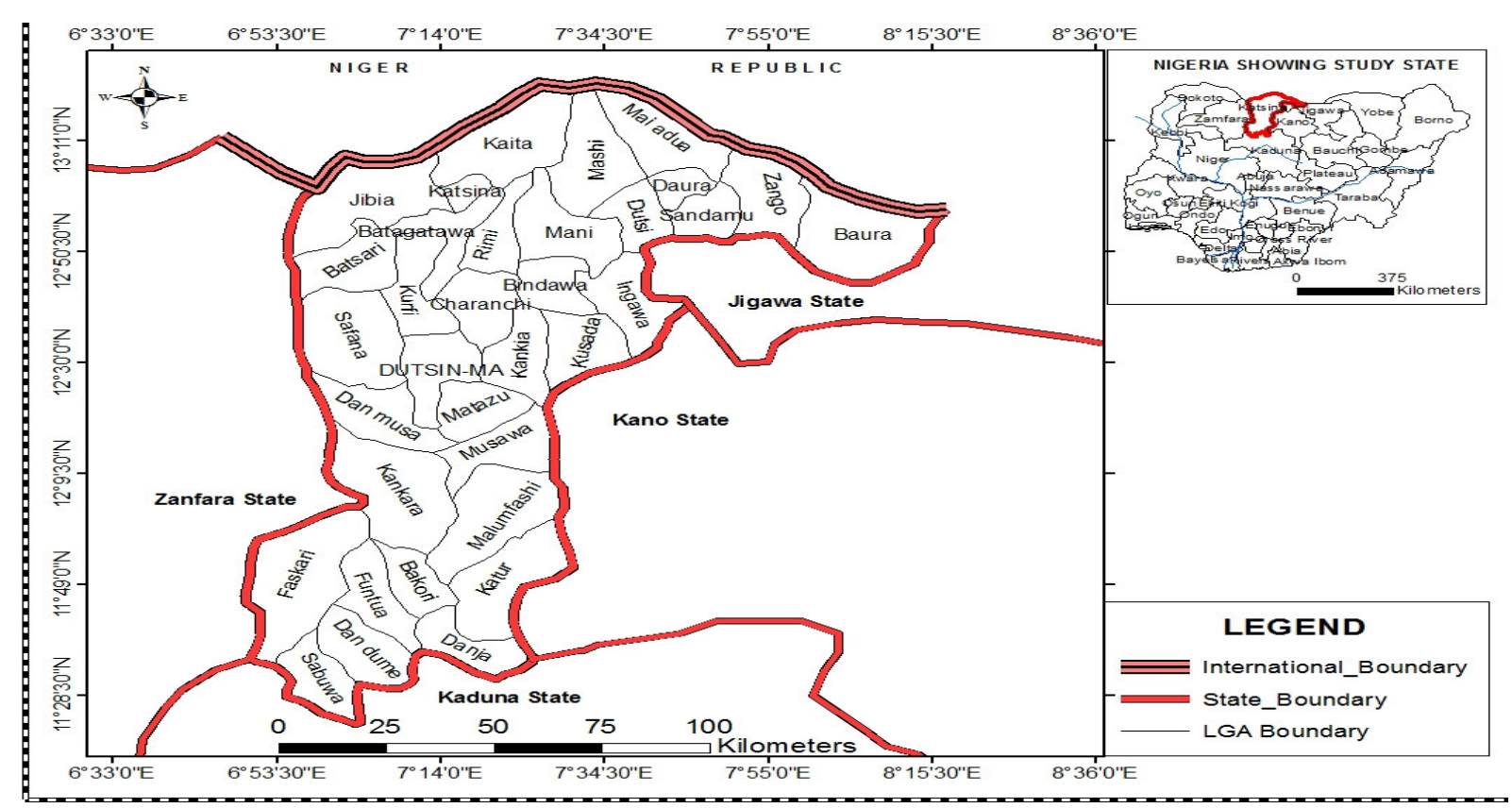

\section{Figure 1.1: Kastina State Showing LGAs}

The area enjoys a hot semi-arid climate according to the Koppen climate classification system (The world Gazetter, 2012). The temperature of Katsina is usually high all year round with the highest values from the months of January to May being within $43^{\circ} \mathrm{C}$ to $56^{\circ} \mathrm{C}$ and the lowest values from the months of June to September about $12^{\circ} \mathrm{C}$ and again rises from the months of November and December being $63^{\circ} \mathrm{C}$ to $125^{\circ} \mathrm{C}$ (Climate Data sheet for Katsina state, 2012).

The vegetation of Katsina state is the Sudan Semi-Arid enriched with varieties of Grasslands, Shrubs, trees and the spare drought resistant trees (Enger and Smith, 2000). Many of the trees are also resistant to fire as they are involved in Nitrogen fixation and also provide shades and nesting sites for animals. The predominant animals of the Sudan Savanna vegetation belt of Katsina are the Grazers, Kangaroos, Antelope, Rodents, birds, insects and reptiles. There is usually about $50-150 \mathrm{~cm}$ of rain per year which is not distributed evenly throughout the year (Enger \& Smith, 2000).

The people of Katsina state are mainly agricultural and fishing society. They cultivate rice, yam, millet, Guinea corn, onions, tomatoes, sorghum, maize (Fediji et al, 2006). Due to the availability of vast landmass, the people practiced large scale cultivation of crops and commercial agriculture (Fediji,Adeoguk \& Kaliada, 2006). The people also engage in artisan fishing as there is the presence of several rivers and water bodies in the state. Also, trading, craft making such as building of cane chairs, hats boat making etc to earn a living. These activities are tremendously importance as they provide huge economic potential to the people of the area. Huge amount of revenue are generated and the people in the rural areas depends on the revenues from them. The people also engaged in wanting of wild life, lumbering and local craft production. The people also engaged in local cottage industry in which they produced goods that are sold to the outside world. They produced Groundnut and Groundnut oil and sugar. These activities the Katsina people engage in, are activities that can easily be affected by climate change.

This research adopted the cross sectional research design. The data for this study were generated from the administration of questionnaire on respondents in the study area. As for the population, the study area comprised of all the thirty four (34) local Government Areas of Katsina State with a total population of 5,801,584 persons as at the Nigerian population census of 2006 (NPC, 2006); when this population is projected using a growth rate of $3 \%$ the population of the state becomes 8,030,749 Million persons as of 2017. Thus, to ascertain the sample size for this study, the total number of Households in the 34 Local Government areas was determined to be 1146159 and to further determine the total number of Household to a sizable sample in the LGAs, the Taro Yamane formula was used (see equation 1). Thus 400 households is the sample size for this study.

The Taro Yamane formula is given as: $n=\frac{N}{1+N(e)^{2}}($ Sule, 2005) ......Eq 1

Where $\mathrm{n}=$ The same size sought

$\mathrm{N}=$ The finite population

$\mathrm{e}=$ Level of significance $(5 \%)$

$\mathrm{I}=$ Unity 


$$
\text { Thus, } \begin{aligned}
n= & \frac{N}{1+N(e)^{2}} \\
& =\frac{1146159}{1+7.54(0.5)^{2}} \\
& =\frac{1146159}{1+1146159(0.0025)^{2}} \\
& =\frac{1146159}{2,793,635}=399.98=\underline{\underline{400}}
\end{aligned}
$$

The sampling procedure adopted in this study is the multi stage sampling technique. This method became relevant because, it helped the researcher to break the whole study area into sample units with which the study was conducted, using the vegetation belts. Secondly, the stratification was necessitated, due to the fact that, the researcher wanted to show the spatial variations in the phenomena of inquiry, since there is a slight difference in the vegetal cover as one moves from the south to north of the state, there should also be a corresponding difference in the rates of effects of climate change and the consequent adaptive measures applied. The first stage of the multistage sampling was therefore achieved when the area (Katsina State) was calibrated into three districts. The second stage was achieved when the purposive sampling technique, was used to select four communities from each of the inherent local government areas of the zones. The purposive sampling technique was used because the researcher had a fair knowledge of the rural settlements most hit by the climate change phenomenon. Again, sampling the whole communities was not realistic, since they all do not depend on agriculture and the rural resources for survival. The third stage of the multistage sampling technique was achieved when one in every $5^{\text {th }}$ household were selected as points of inquiry in the selected communities using the systematic sampling technique, there after the copies of questionnaire were administered to the selected heads of households in the sample communities. The research instrument was subjected to face and content validation by experts in the field of climate change. This was necessitated by the need for the items on the instrument to measure what they are supposed to measure and do so consistently. Furthermore, the instrument's reliability was achieved using the Pearson's correlation coefficient to compute the scores of selected respondents ( 20 household heads) who completed the instrument twice (with a two weeks interval). The correlation coefficients varied across the sections of the instrument although it ranged between $0.67 \& 0.88$; and the grand reliability significance was $r=0.81$, at $\mathrm{p}<0.005$.The data obtained for the study were presented in tables, and statistical diagrams. While analyses of data was achieved using the Kruskal Wallis difference in the means of samples' test.

\section{Results and Discussion of findings}

Table 1 is about the perception of respondents regarding climate change. In Bakori, respondents that suggested there had been increase in temperature and decreasing rainfall in the area accounted for $22.2 \%$. The respondents that suggested that there has been disruption in the patterns of rainfall and temperature accounted for $11.1 \%$, while those that suggested that, there had been extreme temperature due to emissions of obnoxious gases accounted for $44.4 \%$ of the total respondents. The respondents that suggested that the climate change has resulted in the drought and flooding conditions now experienced in the area account for $11.1 \%$ of the total respondents; while $11.1 \%$ of the total respondents suggested that, climate change phenomenon is responsible for abysmal scarcity of atmospheric moisture, desertification, eutrophication of water bodies and degradation of land and vegetal covers. In Batagarawa, respondents that suggested there had been increase in temperature and decreasing rainfall in the area accounted for $23 \%$. The respondents that suggested that there has been disruption in the patterns of rainfall and temperature accounted for $15.4 \%$, while those that suggested that, there had been extreme temperature due to emissions of obnoxious gases accounted for $23 \%$ of the total respondents. The respondents that suggested that the climate change has resulted in the drought and flooding conditions now experienced in the area account for $23 \%$ of the total respondents; while $15.4 \%$ of the total respondents suggested that, climate change phenomenon is responsible for abysmal scarcity of atmospheric moisture, desertification, eutrophication of water bodies and degradation of land and vegetal covers.

In Batsari, respondents that suggested there had been increase in temperature and decreasing rainfall in the area accounted for $7.1 \%$. The respondents that suggested that there has been disruption in the patterns of rainfall and temperature accounted for $21.4 \%$, while those that suggested that, there had been extreme temperature due to emissions of obnoxious gases accounted for $28.6 \%$ of the total respondents. The respondents that suggested that the climate change has resulted in the drought and flooding conditions now experienced in the area account for $14.3 \%$ of the total respondents; while $28.6 \%$ of the total respondents suggested that, climate change phenomenon is responsible for abysmal scarcity of atmospheric moisture, desertification, eutrophication of water bodies and 
degradation of land and vegetal covers.

In Baure, respondents that suggested there had been increase in temperature and decreasing rainfall in the area accounted for $0 \%$. The respondents that suggested that there has been disruption in the patterns of rainfall and temperature accounted for $28.6 \%$, while those that suggested that, there had been extreme temperature due to emissions of obnoxious gases accounted for $42.9 \%$ of the total respondents. The respondents that suggested that the climate change has resulted in the drought and flooding conditions now experienced in the area account for $28.6 \%$ of the total respondents; while $0 \%$ of the total respondents suggested that, climate change phenomenon is responsible for abysmal scarcity of atmospheric moisture, desertification, eutrophication of water bodies and degradation of land and vegetal covers.

In Jibia, respondents that suggested there had been increase in temperature and decreasing rainfall in the area accounted for $33.3 \%$. The respondents that suggested that there has been disruption in the patterns of rainfall and temperature accounted for $25 \%$, while those that suggested that, there had been extreme temperature due to emissions of obnoxious gases accounted for $8.3 \%$ of the total respondents. The respondents that suggested that the climate change has resulted in the drought and flooding conditions now experienced in the area account for $25 \%$ of the total respondents; while $8.3 \%$ of the total respondents suggested that, climate change phenomenon is responsible for abysmal scarcity of atmospheric moisture, desertification, eutrophication of water bodies and degradation of land and vegetal covers.

In Kafur, respondents that suggested there had been increase in temperature and decreasing rainfall in the area accounted for $7.7 \%$. The respondents that suggested that there has been disruption in the patterns of rainfall and temperature accounted for $30.8 \%$, while those that suggested that, there had been extreme temperature due to emissions of obnoxious gases accounted for $15.4 \%$ of the total respondents. The respondents that suggested that the climate change has resulted in the drought and flooding conditions now experienced in the area account for $15.4 \%$ of the total respondents; while $30.8 \%$ of the total respondents suggested that, climate change phenomenon is responsible for abysmal scarcity of atmospheric moisture, desertification, eutrophication of water bodies and degradation of land and vegetal covers. The summary of respondents perception on different items are displayed in table 1 below

Table 1: Perception of Climate Change in Katsina state

\begin{tabular}{|c|c|c|c|c|c|c|c|c|c|c|c|c|c|}
\hline \multirow[t]{2}{*}{$\mathbf{S} / \mathbf{N}$} & \multirow{2}{*}{$\begin{array}{c}\text { LGA } \\
\text { Name }\end{array}$} & \multicolumn{2}{|c|}{$\mathbf{A}$} & \multicolumn{2}{|c|}{ B } & \multicolumn{2}{|c|}{$\mathbf{C}$} & \multicolumn{2}{|c|}{ D } & \multicolumn{2}{|c|}{$\mathbf{E}$} & \multirow[t]{2}{*}{ total } & \multirow[t]{2}{*}{$\%$} \\
\hline & & Frq & $\%$ & Frq & $\%$ & Frq & $\%$ & Frq & $\%$ & frq & $\%$ & & \\
\hline 1 & Bakori & 2 & 22.2 & 1 & 11.1 & 4 & 44.4 & 1 & 11.1 & 1 & 11.1 & 9 & 100 \\
\hline 2 & Batagarawa & 3 & 23 & 2 & 15.4 & 3 & 23 & 3 & 23 & 2 & 15.4 & 13 & 100 \\
\hline 3 & Batsari & 1 & 7.1 & 3 & 21.4 & 4 & 28.6 & 2 & 14.3 & 4 & 28.6 & 14 & 100 \\
\hline 4 & Baure & 00 & 00 & 2 & 28.6 & 3 & 42.9 & 2 & 28.6 & 00 & 00 & 7 & 100 \\
\hline 5 & Binduwa & 1 & 10 & 3 & 30 & 2 & 20 & 1 & 10 & 3 & 30 & 10 & 100 \\
\hline 6 & Charanchi & 00 & 00 & 2 & 20 & 3 & 30 & 3 & 30 & 2 & 20 & 10 & 100 \\
\hline 7 & Dan musa & 2 & 25 & 2 & 25 & 00 & 00 & 3 & 37.5 & 1 & 12.5 & 8 & 100 \\
\hline 8 & Dandurne & 1 & 10 & 00 & 00 & 4 & 40 & 3 & 30 & 2 & 20 & 10 & 100 \\
\hline 9 & Danja & 3 & 33.3 & 1 & 11.1 & 3 & 33.3 & 1 & 11.1 & 1 & 11.1 & 9 & 100 \\
\hline 10 & Daura & 2 & 13.3 & 1 & 6.7 & 5 & 33.3 & 3 & 20 & 4 & 26.7 & 15 & 100 \\
\hline 11 & Dustin - ma & 00 & 00 & 4 & 36.4 & 3 & 27.3 & 2 & 18.2 & 2 & 18.2 & 11 & 100 \\
\hline 12 & Dutsi & 2 & 25 & 2 & 25 & 3 & 37.5 & 00 & 00 & 1 & 12.5 & 8 & 100 \\
\hline 13 & Faskari & 2 & 16.7 & 4 & 33.3 & 3 & 25 & 00 & 00 & 3 & 25 & 12 & 100 \\
\hline 14 & Funtua & 3 & 18.8 & 2 & 12.5 & 4 & 25 & 4 & 25 & 3 & 18.8 & 16 & 100 \\
\hline 15 & Ingawa & 3 & 27.3 & 4 & 36.4 & 00 & 00 & 2 & 18.2 & 2 & 18.2 & 11 & 100 \\
\hline 16 & Jibia & 4 & 33.3 & 3 & 25 & 1 & 8.3 & 3 & 25 & 1 & 8.3 & 12 & 100 \\
\hline 17 & Kafur & 1 & 7.7 & 4 & 30.8 & 2 & 15.4 & 2 & 15.4 & 4 & 30.8 & 13 & 100 \\
\hline 18 & Kaita & 3 & 23.1 & 3 & 23.1 & 4 & 30.8 & 00 & 00 & 3 & 23.1 & 13 & 100 \\
\hline 19 & Kankara & 2 & 11.8 & 4 & 23.5 & 3 & 17.6 & 2 & 11.8 & 6 & 35.3 & 17 & 100 \\
\hline 20 & Kankia & 2 & 20 & 2 & 20 & 2 & 20 & 1 & 10 & 3 & 30 & 10 & 100 \\
\hline 21 & Katsina & 2 & 9 & 5 & 22.7 & 9 & 40.9 & 4 & 18.2 & 2 & 9 & 22 & 100 \\
\hline 22 & Kurfi & 1 & 12.5 & 4 & 50 & 2 & 25 & 00 & 00 & 1 & 12.5 & 8 & 100 \\
\hline 23 & Kusada & 00 & 00 & 00 & 00 & 00 & 00 & 4 & 57.1 & 3 & 42.9 & 7 & 100 \\
\hline 24 & Maiadua & 2 & 14.3 & 3 & 21.4 & 2 & 14.3 & 4 & 28.6 & 3 & 21.4 & 14 & 100 \\
\hline 25 & Malumfashi & 2 & 15.4 & 1 & 7.7 & 4 & 30.8 & 2 & 15.4 & 4 & 30.8 & 13 & 100 \\
\hline 26 & Mani & 2 & 15.4 & 00 & 00 & 3 & 23.1 & 6 & 46.2 & 2 & 15.4 & 13 & 100 \\
\hline 27 & Mashi & 4 & 33.3 & 00 & 00 & 7 & 58.3 & 00 & 00 & 1 & 8.3 & 12 & 100 \\
\hline 28 & Matazu & 1 & 12.5 & 3 & 37.5 & 3 & 37.5 & 00 & 00 & 1 & 12.5 & 8 & 100 \\
\hline 29 & Musawa & 2 & 16.7 & 4 & 33.3 & 2 & 16.7 & 1 & 8.3 & 3 & 25 & 12 & 100 \\
\hline
\end{tabular}




\begin{tabular}{|c|c|c|c|c|c|c|c|c|c|c|c|c|c|}
\hline \multirow[t]{2}{*}{$\mathbf{S} / \mathbf{N}$} & \multirow{2}{*}{$\begin{array}{c}\text { LGA } \\
\text { Name }\end{array}$} & \multicolumn{2}{|c|}{$\mathbf{A}$} & \multicolumn{2}{|c|}{ B } & \multicolumn{2}{|c|}{$\mathrm{C}$} & \multicolumn{2}{|c|}{ D } & \multicolumn{2}{|c|}{$\mathbf{E}$} & \multirow[t]{2}{*}{ total } & \multirow[t]{2}{*}{$\%$} \\
\hline & & Frq & $\%$ & Frq & $\%$ & Frq & $\%$ & Frq & $\%$ & frq & $\%$ & & \\
\hline 30 & Rimi & 3 & 27.3 & 4 & 36.4 & 00 & 00 & 2 & 18.2 & 2 & 18.2 & 11 & 100 \\
\hline 31 & Subuwa & 00 & 00 & 3 & 30 & 4 & 40 & 00 & 00 & 3 & 30 & 10 & 100 \\
\hline 32 & Safana & 2 & 15.4 & 1 & 7.7 & 4 & 30.8 & 2 & 15.4 & 4 & 30.8 & 13 & 100 \\
\hline 33 & Sandamu & 2 & 20 & 5 & 50 & 3 & 30 & 00 & 00 & 00 & 00 & 10 & 100 \\
\hline 34 & $\begin{array}{l}\text { Zando } \\
\text { Total }\end{array}$ & 1 & 9 & 3 & 27.3 & 1 & 9 & 2 & 18.2 & 4 & 36.4 & $\begin{array}{l}11 \\
392\end{array}$ & 100 \\
\hline
\end{tabular}

N.B: A refers to General increasing temperature and decreasing rain fall; $B$ refers to Disruption on the temperature and rain fall pattern/regime of the place; $C$ refers to Temperature extreme due to emission of obnoxious gases; $D$ refers to Extreme weather and climate conditions that result to drought and flooding; $E$ refers to The abysmal scarcity of moisture laden atmospheric \& Phenomenon of desertification and eutrophication of water bodies, degradation of land and vegetation

In Kankia, respondents that suggested there had been increase in temperature and decreasing rainfall in the area accounted for $20 \%$. The respondents that suggested that there has been disruption in the patterns of rainfall and temperature accounted for $20 \%$, while those that suggested that, there had been extreme temperature due to emissions of obnoxious gases accounted for $20 \%$ of the total respondents. The respondents that suggested that the climate change has resulted in the drought and flooding conditions now experienced in the area account for $10 \%$ of the total respondents; while $30 \%$ of the total respondents suggested that, climate change phenomenon is responsible for abysmal scarcity of atmospheric moisture, desertification, eutrophication of water bodies and degradation of land and vegetal covers.

In Katsina, respondents that suggested there had been increase in temperature and decreasing rainfall in the area accounted for $9 \%$. The respondents that suggested that there has been disruption in the patterns of rainfall and temperature accounted for $22.7 \%$, while those that suggested that, there had been extreme temperature due to emissions of obnoxious gases accounted for $40.9 \%$ of the total respondents. The respondents that suggested that the climate change has resulted in the drought and flooding conditions now experienced in the area account for $18.2 \%$ of the total respondents; while $9 \%$ of the total respondents suggested that, climate change phenomenon is responsible for abysmal scarcity of atmospheric moisture, desertification, eutrophication of water bodies and degradation of land and vegetal covers.

In Kurfi, respondents that suggested there had been increase in temperature and decreasing rainfall in the area accounted for $12.5 \%$. The respondents that suggested that there has been disruption in the patterns of rainfall and temperature accounted for $50 \%$, while those that suggested that, there had been extreme temperature due to emissions of obnoxious gases accounted for $25 \%$ of the total respondents. The respondents that suggested that the climate change has resulted in the drought and flooding conditions now experienced in the area account for $0 \%$ of the total respondents; while $12.5 \%$ of the total respondents suggested that, climate change phenomenon is responsible for abysmal scarcity of atmospheric moisture, desertification, eutrophication of water bodies and degradation of land and vegetal covers.

In Kusada, respondents that suggested there had been increase in temperature and decreasing rainfall in the area accounted for $0 \%$. The respondents that suggested that there has been disruption in the patterns of rainfall and temperature accounted for $0 \%$, while those that suggested that, there had been extreme temperature due to emissions of obnoxious gases accounted for $0 \%$ of the total respondents. The respondents that suggested that the climate change has resulted in the drought and flooding conditions now experienced in the area account for $57.1 \%$ of the total respondents; while $42.9 \%$ of the total respondents suggested that, climate change phenomenon is responsible for abysmal scarcity of atmospheric moisture, desertification, eutrophication of water bodies and degradation of land and vegetal covers.

Table 2 displayed the responses of the respondents regarding climate change impacts on livelihood in the study area. In Bakori $11.1 \%$ the total respondents suggested that climate change has impacted on natural capital assets such as vegetation, grass land water bodies and soil quality. On the other hand, $33.3 \%$ the total respondents suggested that climate change affects cost of labour in the area by forcing the youth to migrate $0 \%$ the total respondents suggested that climate change has caused completed reduction in financial capital assets resulting to low level of household income and savings. Nevertheless, 55.5\% the total respondents suggested that climate change impact explains the general disequilibrium in the natural ecological balance reduced social capital assets such as networks, cooperatives and associations. $0 \%$ of the respondents suggested that assets such as housing, hospital and the general physical decay is as a result of the effects of climate change.

In Batagarawa, $15.4 \%$ the total respondents suggested that climate change has impacted on natural capital assets such as vegetation, grass land water bodies and soil quality. On the other hand, $15.4 \%$ the total respondents suggested that climate change affects cost of labour in the area by forcing the youth to migrate $23.1 \%$ the total respondents suggested that climate change has caused completed reduction in financial capital assets resulting to 
low level of household income and savings. Nevertheless, $23.1 \%$ the total respondents suggested that climate change impact explains the general disequilibrium in the natural ecological balance reduced social capital assets such as networks, cooperatives and associations. $23.1 \%$ of the respondents suggested that assets such as housing, hospital and the general physical decay is as a result of the effects of climate change.

In Batsari, 35.7\% the total respondents suggested that climate change has impacted on natural capital assets such as vegetation, grass land water bodies and soil quality. On the other hand, $7.1 \%$ the total respondents suggested that climate change affects cost of labour in the area by forcing the youth to migrate $35.7 \%$ the total respondents suggested that climate change has caused completed reduction in financial capital assets resulting to low level of household income and savings. Nevertheless, $7.1 \%$ the total respondents suggested that climate change impact explains the general disequilibrium in the natural ecological balance reduced social capital assets such as networks, cooperatives and associations. $14.3 \%$ of the respondents suggested that assets such as housing, hospital and the general physical decay is as a result of the effects of climate change.

In Baure $14.3 \%$ the total respondents suggested that climate change has impacted on natural capital assets such as vegetation, grass land water bodies and soil quality. On the other hand, $14.3 \%$ the total respondents suggested that climate change affects cost of labour in the area by forcing the youth to migrate $14.3 \%$ the total respondents suggested that climate change has caused completed reduction in financial capital assets resulting to low level of household income and savings. Nevertheless, $0 \%$ the total respondents suggested that climate change impact explains the general disequilibrium in the natural ecological balance reduced social capital assets such as networks, cooperatives and associations. $57.1 \%$ of the respondents suggested that assets such as housing, hospital and the general physical decay is as a result of the effects of climate change.

In Bindawa $0 \%$ the total respondents suggested that climate change has impacted on natural capital assets such as vegetation, grass land water bodies and soil quality. On the other hand, $10 \%$ the total respondents suggested that climate change affects cost of labour in the area by forcing the youth to migrate $30 \%$ the total respondents suggested that climate change has caused completed reduction in financial capital assets resulting to low level of household income and savings. Nevertheless, $10 \%$ the total respondents suggested that climate change impact explains the general disequilibrium in the natural ecological balance reduced social capital assets such as networks, cooperatives and associations. $30 \%$ of the respondents suggested that assets such as housing, hospital and the general physical decay is as a result of the effects of climate change.

In Daura $46.7 \%$ the total respondents suggested that climate change has impacted on natural capital assets such as vegetation, grass land water bodies and soil quality. On the other hand, $13.3 \%$ the total respondents suggested that climate change affects cost of labour in the area by forcing the youth to migrate $6.7 \%$ the total respondents suggested that climate change has caused completed reduction in financial capital assets resulting to low level of household income and savings. Nevertheless, $6.7 \%$ the total respondents suggested that climate change impact explains the general disequilibrium in the natural ecological balance reduced social capital assets such as networks, cooperatives and associations. $26.7 \%$ of the respondents suggested that assets such as housing, hospital and the general physical decay is as a result of the effects of climate change.

In Dutsima 36.4\% the total respondents suggested that climate change has impacted on natural capital assets such as vegetation, grass land water bodies and soil quality. On the other hand, $18.2 \%$ the total respondents suggested that climate change affects cost of labour in the area by forcing the youth to migrate $18.2 \%$ the total respondents suggested that climate change has caused completed reduction in financial capital assets resulting to low level of household income and savings. Nevertheless, $9 \%$ the total respondents suggested that climate change impact explains the general disequilibrium in the natural ecological balance reduced social capital assets such as networks, cooperatives and associations. $18.2 \%$ of the respondents suggested that assets such as housing, hospital and the general physical decay is as a result of the effects of climate change. Table 2 summarizes the distribution of respondents perception of climate change impacts on livelihood. 
Table 2:Distribution of Response on Climate Change impacts on livelihood by LGA

\begin{tabular}{|c|c|c|c|c|c|c|c|c|c|c|c|c|c|}
\hline \multirow[t]{2}{*}{$\mathbf{S} / \mathbf{N}$} & \multirow[t]{2}{*}{ LGA Name } & \multicolumn{2}{|c|}{ A } & \multicolumn{2}{|c|}{ B } & \multicolumn{2}{|c|}{$\mathrm{C}$} & \multicolumn{2}{|c|}{ D } & \multicolumn{2}{|c|}{$\mathbf{E}$} & \multirow[t]{2}{*}{ total } & \multirow[t]{2}{*}{$\%$} \\
\hline & & Frq & $\%$ & Frq & $\%$ & Frq & $\%$ & Frq & $\%$ & frq & $\%$ & & \\
\hline 1 & Bakori & 1 & 11.1 & 3 & 33.3 & 00 & 00 & 5 & 55.5 & 00 & 00 & 9 & 100 \\
\hline 2 & Batagarawa & 2 & 15.4 & 2 & 15.4 & 3 & 23.1 & 3 & 23.1 & 3 & 23.1 & 13 & 100 \\
\hline 3 & Batsari & 5 & 35.7 & 1 & 7.1 & 5 & 35.7 & 1 & 7.1 & 2 & 14.3 & 14 & 100 \\
\hline 4 & Baure & 1 & 14.3 & 1 & 14.3 & 1 & 14.3 & 00 & 00 & 4 & 57.1 & 7 & 100 \\
\hline 5 & Binduwa & 00 & 00 & 1 & 10 & 3 & 30 & 1 & 10 & 3 & 30 & 10 & 100 \\
\hline 6 & Charanchi & 3 & 30 & 1 & 10 & 00 & 00 & 4 & 40 & 2 & 20 & 10 & 100 \\
\hline 7 & Dan musa & 1 & 12.5 & 2 & 25 & 00 & 00 & 00 & 00 & 5 & 62.5 & 8 & 100 \\
\hline 8 & Dandurne & 6 & 60 & 3 & 30 & 00 & 00 & 00 & 00 & 1 & 10 & 10 & 100 \\
\hline 9 & Danja & 2 & 22.2 & 2 & 22.2 & 1 & 11.1 & 00 & 00 & 4 & 44.4 & 9 & 100 \\
\hline 10 & Daura & 7 & 46.7 & 2 & 13.3 & 1 & 6.7 & 1 & 6.7 & 4 & 26.7 & 15 & 100 \\
\hline 11 & Dustin - ma & 4 & 36.4 & 2 & 18.2 & 2 & 18.2 & 1 & 9 & 2 & 18.2 & 11 & 100 \\
\hline 12 & Dutsi & 3 & 37.5 & 1 & 12.5 & 00 & 00 & 00 & 00 & 4 & 50 & 8 & 100 \\
\hline 13 & Faskari & 2 & 16.7 & 1 & 8.3 & 2 & 16.7 & 6 & 50 & 3 & 25 & 12 & 100 \\
\hline 14 & Funtua & 2 & 12.5 & 2 & 12.5 & 3 & 18.8 & 7 & 43.8 & 2 & 12.5 & 16 & 100 \\
\hline 15 & Ingawa & 2 & 18.2 & 00 & 00 & 00 & 00 & 6 & 54.5 & 3 & 27.3 & 11 & 100 \\
\hline 16 & Jibia & 3 & 25 & 4 & 33.3 & 2 & 16.7 & 2 & 16.7 & 1 & 8.3 & 12 & 100 \\
\hline 17 & Kafur & 3 & 23.1 & 4 & 30.8 & 3 & 23.1 & 2 & 15.4 & 1 & 7.7 & 13 & 100 \\
\hline 18 & Kaita & 9 & 69.2 & 2 & 15.4 & 1 & 7.7 & 00 & 00 & 1 & 7.7 & 13 & 100 \\
\hline 19 & Kankara & 5 & 29.4 & 3 & 17.6 & 5 & 29.4 & 2 & 11.8 & 2 & 11.8 & 17 & 100 \\
\hline 20 & Kankia & 4 & 40 & 2 & 20 & 3 & 30 & 1 & 10 & 00 & 00 & 10 & 100 \\
\hline 21 & Katsina & 5 & 22.7 & 3 & 13.6 & 8 & 36.4 & 4 & 18.2 & 2 & 9 & 22 & 100 \\
\hline 22 & Kurfi & 6 & 75 & 00 & 00 & 00 & 00 & 00 & 00 & 2 & 25 & 8 & 100 \\
\hline 23 & Kusada & 2 & 28.6 & 00 & 00 & 2 & 28.6 & 3 & 42.9 & 00 & 00 & 7 & 100 \\
\hline 24 & Maiadua & 2 & 14.3 & 4 & 28.6 & 1 & 7.14 & 2 & 14.3 & 5 & 35.7 & 14 & 100 \\
\hline 25 & Malumfashi & 2 & 15.4 & 3 & 23.1 & 00 & 00 & 2 & 15.4 & 6 & 46.2 & 13 & 100 \\
\hline 26 & Mani & 1 & 7.7 & 2 & 15.4 & 6 & 46.2 & 2 & 15.4 & 2 & 15.4 & 13 & 100 \\
\hline 27 & Mashi & 1 & 8.3 & 2 & 16.7 & 4 & 33.3 & 1 & 8.3 & 4 & 33.3 & 12 & 100 \\
\hline 28 & Matazu & 1 & 12.5 & 1 & 12.5 & 00 & 00 & 5 & 62.5 & 1 & 12.5 & 8 & 100 \\
\hline 29 & Musawa & 2 & 16.7 & 2 & 16.7 & 00 & 00 & 4 & 33.3 & 4 & 33.3 & 12 & 100 \\
\hline 30 & Rimi & 2 & 18.2 & 1 & 9 & 4 & 36.4 & 1 & 9 & 3 & 27.3 & 11 & 100 \\
\hline 31 & Subuwa & 2 & 20 & 4 & 40 & 3 & 30 & 1 & 10 & 00 & 00 & 10 & 100 \\
\hline 32 & Safana & 1 & 7.7 & 3 & 23.1 & 4 & 30.8 & 3 & 23.1 & 2 & 15.4 & 13 & 100 \\
\hline 33 & Sandamu & 6 & 60 & 00 & 00 & 00 & 00 & 00 & 00 & 4 & 40 & 10 & 100 \\
\hline 34 & Zando & 1 & 9 & 7 & 63.6 & 00 & 00 & 1 & 9 & 2 & 18.2 & 11 & 100 \\
\hline & Total & & & & & & & & & & & 392 & \\
\hline
\end{tabular}

N.B: A refers to Destruction of Natural capital Assets such as vegetation Grass land, Arable land, water bodies and soil quality; B refers to Reduction of Human capital Assets by way of increased severity of labour migration, reduced labour capacity, deficiency in skills and education; $C$ refers to Complete reduction in financial capital Assets resulting to low level of household income and savings, increased poverty, malnutrition and low investments, $D$ refers to General disequilibrium in Natural Ecological balance, reduced social capital Assets such as Networks, cooperatives and Associations; E refers to Poor physical capital Assets such as Housing, schools and Hospital and general physical decay

From the data in table 2, increase in the loss of agricultural land and soil quality due to erosion and reduced soil fertility has been observed as some of the impacts of climate variability. To this facts, almost $70 \%$ and over $70 \%$ respectively of the respondents agreed to this while $30.4 \%$ and $27 \%$, of the respondents disagreed with the effects so mentioned. Again, on the impact of climate variability as solely responsible for increased livestock productivity and reduced livestock productivity, $44.4 \%$ of the respondent agreed to the fact that it increases livestock productivity while over $50 \%$ disagreed with it. On the conversely; $55.6 \%$ agreed that climate variability reduced livestock production while $44.4 \%$ of the respondent said they disagreed. 
Table 3:Distribution of Extent of Climate Variability effects on Socio - Economic Activities

\begin{tabular}{|c|c|c|c|c|c|c|c|c|c|}
\hline & Climate Variability Impact & & & Ag & eed & Dis: & rreed & $\begin{array}{c}\text { Str } \\
\text { Disa }\end{array}$ & $\begin{array}{l}\text { ngly } \\
\text { reed }\end{array}$ \\
\hline $\mathbf{S} / \mathbf{N}$ & & $\mathbf{F}$ & $\%$ & $\mathbf{F}$ & $\%$ & $\mathbf{F}$ & $\%$ & $\mathbf{F}$ & $\%$ \\
\hline 1 & Onset rainfall is now delay & 182 & 26.0 & 96 & 24.5 & 86 & 22.0 & 108 & 27.6 \\
\hline 2 & Increased in earth surface temperature & 149 & 38.0 & 108 & 27.6 & 72 & 18.4 & 63 & 16.1 \\
\hline 3 & Prolong season of drought & 182 & 46.4 & 92 & 23.5 & 64 & 16.3 & 54 & 13.8 \\
\hline 4 & $\begin{array}{l}\text { Increase infrequency and intensity of } \\
\text { flood }\end{array}$ & 92 & 23.5 & 64 & 16.3 & 182 & 46.4 & 54 & 13.8 \\
\hline 5 & Crop yield have reduced significantly & 150 & 38.3 & 186 & 47.4 & 55 & 14.0 & 1 & 0.3 \\
\hline 6 & Crop yield have increased significantly & 104 & 26.5 & 72 & 18.4 & 112 & 28.6 & 164 & 26.5 \\
\hline 7 & $\begin{array}{l}\text { Planting time of crop is now } \\
\text { unpredictable }\end{array}$ & 76 & 19.4 & 84 & 21.4 & 96 & 24.5 & 136 & 34.7 \\
\hline 8 & Increase loss of agric land due to erosion & 132 & 33.7 & 142 & 36.2 & 86 & 22.0 & 32 & 8.2 \\
\hline 9 & Soil fertility has been reduced generally & 152 & 38.9 & 134 & 34.2 & 100 & 25.5 & 6 & 1.5 \\
\hline 10 & Reduced productivity of livestock & 94 & 24.0 & 124 & 31.6 & 102 & 26.0 & 72 & 18.4 \\
\hline 11 & Increase productivity of livestock & 72 & 18.4 & 102 & 26.0 & 94 & 24.0 & 124 & 31.6 \\
\hline 12 & $\begin{array}{l}\text { Increased in pest and disease incidence in } \\
\text { livestock }\end{array}$ & 192 & 49.0 & 84 & 21.4 & 72 & 18.4 & 44 & 11.2 \\
\hline 13 & Non-availability of pasture for livestock & 148 & 37.8 & 120 & 30.6 & 72 & 18.4 & 52 & 13.3 \\
\hline 14 & $\begin{array}{l}\text { Increase in incidence of destructive } \\
\text { windstorms }\end{array}$ & 132 & 33.7 & 150 & 38.4 & 64 & 16.3 & 46 & 11.7 \\
\hline 15 & Increases in poverty rate of farmers & 142 & 36.2 & 144 & 36.7 & 64 & 16.3 & 42 & 10.7 \\
\hline 16 & Decreased in poverty rate of farmers & 68 & 17.3 & 86 & 22.0 & 138 & 35.2 & 100 & 25.5 \\
\hline 17 & Increased cost of crop production & 121 & 30.9 & 115 & 29.3 & 95 & 24.2 & 61 & 15.6 \\
\hline 18 & $\begin{array}{l}\text { Increased loss during strong as a result of } \\
\text { increased intensity of heat }\end{array}$ & 122 & 31.1 & 118 & 30.1 & 99 & 25.3 & 53 & 13.5 \\
\hline 19 & $\begin{array}{l}\text { Increased in uncertainty of the harvesting } \\
\text { time }\end{array}$ & 94 & 24.0 & 89 & 22.7 & 138 & 35.2 & 71 & 18.1 \\
\hline 20 & General reduction in family income & 138 & 35.2 & 94 & 24.0 & 89 & 22.7 & 71 & 18.1 \\
\hline
\end{tabular}

Source: Researcher's Field Survey, 2018.

To increase in pest and disease incidence in livestock and non - availability of pasture for livestock respectively, over $70 \%$ and $68.4 \%$ said they agreed while $21.6 \%$ and $31.7 \%$ said they do not agreed at all. To the issues of increase incidences of destructive windstorms and poverty rate of farmers respectively, the responses of the respondents was that $72.1 \%$ and $72.9 \%$ said they agreed while $28 \%$ and $27 \%$ of the respondents said they disagreed.

Again, on the statement that climate variability decreased rate of farmer poverty and increase cost of crop production, $39.3 \%$ and 60.2 respectively said they agreed while $60.7 \%$ and $39.8 \%$ said they disagreed with the statements. On the issues of increase loss during storage as a result of increased intensity of heat and, increased in uncertainty of the harvesting time, $61.2 \%$ and $46.7 \%$ of the respondents said they agreed to the statements while $38.8 \%$ and $53.3 \%$ respectively said they disagreed. And lastly, from table 4.2 .8 above, on the fact that climate variability leads to general reduction in family income, $59.2 \%$ of the respondent agreed to it while $45.8 \%$ said they disagreed.

Table 4: Kruskal Wallis Result for spatial variation in the perception of climate change effects in the study area

Ranks

\begin{tabular}{llcc}
\hline & Identifiers & N & Mean Rank \\
\hline CAP & South & 10320 & 10923.23 \\
& North & 10240 & 14881.35 \\
& Cantral & 10800 & 11674.21 \\
& Total & 31360 & \\
\hline
\end{tabular}


Table 5: Kruskal Wallis test for significance for spatial variation in the perception of climate change effects in the study area

Test Statistics ${ }^{\mathrm{a}, \mathrm{b}}$

\begin{tabular}{lc}
\hline & CAP \\
\hline Chi-Square & 21303.673 \\
Df & 2 \\
Asymp. Sig. & .000 \\
\hline
\end{tabular}

a. Kruskal Wallis Test

b. Grouping Variable: Identifiers

The impact of climate change on the livelihood and socio-economics of the people was examined in using the Kruskal walis test in table $4.21 \& 4.22$ respectively, using the data gotten from the questionnaire administration. The result revealed that there was statistically significant difference in climate change effects perception in the area at $\mathrm{P}<0.05 \chi^{2}(2)=, 21303.673$ with mean rank of the climate effects perception being, South (10923.2), North (14881.4) and central (11674.2).

\section{Conclusion and recommendation}

This study centred on finding out the effects of climate change on livelihood in the rural areas of Katsina State. The thrust of the study was to identify if there was actually the problem of climate change in the area and the impacts it has on livelihood. Overall the researcher was able to establish that there is climate change problem in the study area which already has serious implications for the livelihood of inhabitants of the study area by reducing livelihood options and requiring more resources to cultivate smaller lands. The climate change problem requires some empirical data inclusion for further analyses and better generalisation; a task this current study has not achieved. Nevertheless, the researchers recommend the following:

a) There is urgent need for both government agencies and non-governmental organisations to intensify the awareness campaigns about climate change and effects it has on livelihood in the area.

b) There is need for the farmers to introduce climate smart agriculture in the study area. This implies identifying and engineering the crop species that would produce better under the current climate condition

c) There is need for afforestation in the area. This will both serve as carbon sink and a climate mitigation option in the area.

\section{References}

Abanigha, C.A (2013). The Land Scape of Northern Nigeria. Allen Publishers.

Abel, A. A. \& Orunoye, E.D (2013). An Assessment of Climate Change in Taraba State, Nigeria. Nigerian Journal of Tropical Geography, 4(2).

Abraham, F., Bamidele, F. S., Adebola, A. J., \& Kobe, I. H. (2011). Climate change mitigating activities and determinants in the rural guinea savannah of Nigeria. Sustainable Agriculture Research, 1(2), 170-177.

Abubakar. A., (2001) Shift in Agriculuture Production in Northern Nigeria. Agricultural Development. 4(1) 04120

Ahmed, G.D \& Bisiku, C.C. (2006). The Impact of Global Warming in the Tropics. Journal of Science and Environment 4 (1) 6 - 8 .

Ajayi., N.O., (2009) Analysis of perception and adaptation strategies of farmers to climate change in ikara local government area of Kaduna state, Nigeria. A thesis submitted to the school of postgraduate studies, Ahmadu Bello University, Zaria.

ASSAR (2015) Vulnerability and Adaptation to Climate Change in the Semi - Arid Region of Africa. Assar Regional Diagnostic Study Africana Austin Water Center for Environmental Research, Travis County, Texas USA.

Band, C.C; Gibson G \& Abel, CC (2013): The Science of Climate Change. Granhane Institute for Climate Change. Discussion Paper 2.

Coeven, O.C and Helfare, D (2014). Climate Change and Livelihood in Subsharan Africa. Welbros Press. Jos.

Ebong, M.O (2006). The System Theory Analysis. Calabar. Wusen Press.

Elisha I., Sawa B. A. \& Lawrence (2017) E.U Evidence of Climate Change and Adaptation Strategies among Grain Farmers in Sokoto State, Nigeria. IOSR Journal of Environmental Science, Toxicology and Food Technology. Volume 11, Issue 3

Farauta B.K, Egbule C.L, Idrisa Y.L, and Agu V.C, (2011) Climate Change and Adaptation Measures in Northern Nigeria: Empirical Situation and Policy Implications. African Technology Policy Studies Network WORKING PAPER SERIES | No. 62

Farauta B.K., Egbule C. L., Idrisa Y. L., \& Agu, V.C. (2011) Farmers' Perceptions of Climate Change and 
Adaptation Strategies in Northern Nigeria: An Empirical Assessment. African Technology Policy Studies Network,

Fediji, T.O; Adeoguk, A.O and Kaliada A.E (2006). Social Activities and Socio - Economic Status of Rural Farmers Cultivating Improved Maize in Kaduna and Katsina States, Nigeria Journal of Agricultural Extension, $\mathrm{Vol}_{2}, \mathrm{Pp} 29-30$.

Fischer, C; Ben B.O and Etop G (2015) Understanding the Impact of Climate Change on Rural Places. Jos. Jethin Press

Gemade, D.O. and Sima, A.D (2015). The Impacts of Climate Change on African Continent and the Way Forward. Journal of Ecology and Natural Environment $\mathrm{Vo}_{7} 256-257$.

Ishaya, S., \& Abaje, I. B. (2008). Indigenous people‘s perception on climate change and adaptation strategies in Jema'a Local Government Area of Kaduna State, Nigeria. Journal of Geography and Regional Planning, 1(8), 13800143.

Krantz L. (2001) The Sustainable Livelihood Approach to Poverty Reduction: An Introduction. SIDA, Division for Policy and Social Economic Analysis. Retrieved from online on Feb 10 ${ }^{\text {th }}$ 2017. Last visit 20 March 2017 MacMillan

Mustafa, A and Yusuf, BC (2012). Impact of Climate Change Agriculture System of the Tropics: A Approach. New York, McGraw Hill Press.

National Population Commission (NPC, 2006).

Nkii, L.B (2013) Health Impact of Global Warming and Climate Change. Peace Review Journal 23 Pp $201-204$.

Ogba, C.C \& Utang, J.O. (2008) The Savanna Vegetation Belt of The Tropics. African Journal of Geographical Studies. 2(31) $24-26$.

Okubokebena, C; Hope, G.B \& Clayton C.B (2014) mainstreaming Adaptation to Climate Change in LDCs. Clim. Policy 4(1) $25-27$.

Oluwo, D.D (2013). Adaptation Investment: A Climate Change Perspective. Jinma. Jinma University Press.

Odjugo, P.A. \& A Ikhuoria, (2003). The impacts of climate change and anthropogenic factors on desertification in the semi00arid region of Nigeria, Global Journal of Environmental Science, 2(2), 11800126 ișepi:

Pascher, UC (2013) Integrating the Science and Academics of global Warming into a Framework. Oxford University Press England.

Sigmond, C.O (2012) Climate Change Adaptation and Cost Benefits Analysis. UNPP Programme Framework. Pp $6-12$.

Scoones, I., (1999). Sustainable Rural Livelihoods: a Framework for Analysis. IDS Working Paper 72. Institute of Development Studies, Brighton, UK

Spencer W. (2011) The Public and Climate Change: The Discovery of Global Warming. Journal of Applied Sciences., 2, $36-37$.

Terdoo F. \& Adekola O. (2014) Perceptions, Knowledge, Adaptation and Socio00Economic Cost of Climate Change in Northern Nigeria. Journal of Agricultural Science; Vol. 6, No. 8;

Udeh, L. E. (2014) Assessment of Farmers' Perception and Adaptation Strategies to Climate Change in Kano State, Nigeria. Unpublished Doctor of Philosophy Dissertation, Department of Geography, Ahamdu Bello University, Zaria. (Unpublished Thesis) 